\title{
Simultaneous detection of three antineoplastic drugs on gloves by liquid chromatography with diode array detector
}

\author{
Adélia Maria Pimenta de Pádua Alcântara, Ricardo Vilela Vitor, Elisabeth Pizzamiglio Vieira, \\ Isarita Martins,*
}

Laboratory of Toxicological Analysis, Department of Clinical and Toxicological Analysis, Federal University of Alfenas

\begin{abstract}
The aim of this study was to develop a method for simultaneous detection of antineoplastic drugs on gloves since, in occupational exposure, the main contamination route is through dermal contact, which may occur via prolonged contact with contaminated surfaces or materials. The assay was performed by liquid chromatography using the following conditions for the detection of 5-fluorouracil (5-FU), methotrexate (MTX) and paclitaxel (TAX): diode array detection and UV quantification at $195 \mathrm{~nm}$ for TAX, at $265 \mathrm{~nm}$ for 5-FU and at $302 \mathrm{~nm}$ for MTX; ODS column $(250 \times 4 \mathrm{~mm}, 5 \mu \mathrm{m})$ with a similar guard column; mobile phase consisted of water $(\mathrm{pH} 4)$-methanol-acetonitrile $(35: 15: 50, \mathrm{v} / \mathrm{v} / \mathrm{v})$ with a flow rate of $1 \mathrm{~mL} \mathrm{~min}^{-1}$. The method presented a linear range from 0.25 to $20 \mu \mathrm{g} \mathrm{mL}^{-1}$ with $\mathrm{r}^{2}$ higher than 0.99 . Repeatability was $\leq 15 \%$ and satisfactory extraction efficiency was obtained when liquid-liquid extraction with ethyl acetate was used for 5-FU and TAX. Satisfactory solid phase extraction was also achieved with $\mathrm{C} 18$ cartridges and elution with methanol for MTX. The diode array detector allowed drug quantification at a concentration $\geq 0.25 \mu \mathrm{g} \mathrm{mL}^{-1}$ in samples, although detection was possible in samples that presented values of around $0.1 \mu \mathrm{g} \mathrm{mL}^{-1}$. The results obtained suggest that the method developed can be applied for the simultaneous determination of the drugs studied and can be considered useful in exposure assessment for health care workers.
\end{abstract}

Uniterms: Antineoplastic drugs/detection. Gloves/toxicologial analysis. High Performance Liquid Chromatography/toxicologial analysis. Occupational exposure.

O objetivo deste estudo foi desenvolver um método para a detecção simultânea de antineoplásicos em luvas, uma vez que, em exposições ocupacionais, a principal via de introdução é a dérmica, por meio de contato prolongado com superfícies e/ou materiais contaminados com tais fármacos. A tecnica de detecção utilizada foi a cromatografia líquida de alta eficiência, com detector de aranjo de diodos, nas seguintes condições: para a detecção de 5-fluorouracila (5-FU), metotrexato (MTX) e paclitaxel (TAX): detecção e quantificação de TAX a $195 \mathrm{~nm}$, de 5-FU a $265 \mathrm{~nm}$ e de MTX a $302 \mathrm{~nm}$; coluna ODS (250 x 4 mm, $5 \mu \mathrm{m})$, com pré-coluna similar; fase móvel constituída de água ( $\mathrm{pH} 4)$-metanol-acetonitrila (35:15:50, $\mathrm{v} / \mathrm{v} / \mathrm{v}$ ), na vazão de $1 \mathrm{~mL} \mathrm{~min}^{-1}$. O método apresentou uma faixa linear de 0,25-20 mg mL ${ }^{-1}, \mathrm{com} \mathrm{r}^{2}>0,99$. O desvio-padrão relativo, para a avaliação da repetibilidade foi $\leq 15 \%$; a recuperação foi satisfatória, empregando extração líquido-líquido, com acetato de etila, para a 5-FU e TAX e extração em fase sólida, com cartuchos de C18 e eluição com metanol, para MTX. O detector de arranjo de diodos permitiu a quantificação dos fármacos, quando presentes nas amostras em concentração $\geq 0,25 \mathrm{mg} \mathrm{mL}^{-1}$, embora a detecção foi possível nas amostras que apresentaram valores em torno de $0,1 \mathrm{mg} \mathrm{mL}^{-1}$. Os resultados obtidos sugerem que o método desenvolvido pode ser aplicado para a determinação simultânea dos fármacos estudados, constituindo ferramenta útil na avaliação da exposição dos trabalhadores as fármacos antineoplásicos.

Unitermos: Antineoplásicos/detecção. Luvas/análise toxicológica. Cromatografia líquida de alta eficiência/análise toxicológica.

\footnotetext{
*Correspondence: I. Martins. Laboratory of Toxicological Analysis, Department of Clinical and Toxicological Analysis, Federal University of Alfenas-MG/ Brazil. Av. Gabriel Monteiro da Silva, 700- Alfenas. Minas Gerais, Brazil. CEP: 37130.000. E-mail address: isarita@unifal-mg.edu.br
} 


\section{INTRODUCTION}

There is a tumour risk associated to the treatment of patients with antineoplastic drugs. This can been confirmed by considering the "second tumour" risk among patients, which increases as a function of survival period and is also characterized by an increased incidence of tumours among patients treated for non-neoplastic diseases, such as immunosuppression before organ transplantation (Alessio et al., 1996).

Groups exposed to antineoplastic drugs include: patients and family members, individuals working in the pharmaceutical industry, workers who prepare and administer the antineoplastic drugs, as well as cleaning personnel and researchers (Sorsa, Anderson, 1996).

Occupational exposure to these agents has been recognized as a potential hazard since the 1970s. Based on current knowledge, it is impossible to set a level of exposure that is considered safe. The question of whether exposure can be diminished by a reduction in handling is difficult to answer. Normally, it is reasonable to assume a positive correlation between use and exposure and currently, no recommended exposure limits (RELs), permissible exposure limits (PELs), or threshold limit values (TLVs ${ }^{\circledR}$ ) have been established for antineoplastic drugs (Sessink et al., 1997; NIOSH, 2004). A balance must be found so as to continue the use of these beneficial drugs in patients while also assuring the health of personnel administering them.

Biological and environmental monitoring is essential to identify the main exposure routes and to quantify the potential health risks. However, risk assessment calls for accurate standardized sampling techniques and analytical methods for determining the presence of these drugs in different samples (Turci et al., 2003).

In most of the current chemotherapy protocols, antineoplastic drugs are combined, each having a different mechanism of action. As a consequence, healthcare workers may be exposed to a wide variety of these substances (Larson, Khazaeli, Dillon, 2003; Turci et al., 2003). Thus, it is necessary to identify certain substances that can be used as indicators for the presence of these drugs. The antineoplastic drugs of concern include cyclophosphamide, 5-fluorouracil and the platinum coordination compounds (Alessio et al., 1996). Thus, the decision on which agents should be evaluated for exposure should be based on both frequency of use and toxicity of the drugs. Another alternative is to develop methods able to detect multiple compounds simultaneously.

Research has shown that the main exposure route appears to be direct skin contact. Therefore, the drugs should be detected according to the following priorities: a) measurement on surfaces and materials (such as masks and gloves), b) measurement in biological samples and c) measurement in environmental samples (Alessio et al., 1996).

Analysis of surfaces and materials is very useful for evaluating the presence of residual contaminants in workrooms as well as the effectiveness of personal protective equipment. A number of surveys have been carried out in oncology departments and gloves were commonly analyzed for antineoplastic drugs, enabling the evaluation of the potential dermal uptake.

Previous studies have not determined the presence of antineoplastic drugs in cotton gloves worn under the latex gloves or on the inside of gloves as liners (Sessink et al., 1992; Minoia et al., 1998). Also, no statistically significant differences have been observed in the levels of these drugs in biological safety hood surfaces, gloves or infusion bags (Martins, Apostoli, Della Rosa, 2008).

High performance liquid chromatography with ultra-violet detection (HPLC-UV) is the most used method reported in the current literature for the detection of antineoplastic agents. This technique appears to be the most feasible for attaining maximal sensitivity (a lower limit of detection) when used for the detection of multiple antineoplastics in both air and surface samples (Turci et al., 2002; Larson, Khazaeli, Dillon, 2003).

Since workers are exposed to a wide variety of antineoplastic drugs, it is necessary to develop methods able to detect various agents. Currently, acceptable analytical methods do exist for the detection of several antineoplastic drugs, but usually are only available for an individual agent or for small groups of chemically similar agents.

The aim of this study was to develop a HPLC method able to detect the presence of antineoplastic drugs on gloves in a single analysis. The drugs evaluated were methotrexate (MTX), 5-fluorouracil (5-FU) and paclitaxel (TAX). The objective was to obtain an accurate and sensitive liquid chromatographic method for the detection and quantification of these substances, which differ both chemically and structurally (Figure 1 and Table I), for the evaluation of general occupational exposure.

Methotrexate (MTX) is an antimetabolite used in the treatment of certain neoplastic diseases, several forms of psoriasis, and adult rheumatoid arthritis. The degree and severity of the side effects depend on the regimen of administration of this drug. According to the International Agency for Research on Cancer (IARC), MTX is classified as Group 3; it is not classified as to its carcinogenicity to humans, but it is a known mutagen and human teratogen. 5-fluorouracil (5-FU) is an antimetabolite frequently used in the treatment of cancers of the gastrointestinal tract, 
TABLE I - Molar mass, pKa and solubility of three antineoplastic drugs frequently used in clinical practice (Reynolds, 1996; O'Neil, 2006; Scifinder, 2006)

\begin{tabular}{lccl}
\hline Drug & Molar mass & $\mathrm{pKa}$ & Solubility in \\
\hline 5-Fluorouracil & 130 & 7.68 & water and alcohols \\
Methotrexate & 454 & $3.54 / 5.09$ & acidic and basic diluted solutions \\
Paclitaxel & 854 & Not available & organic solvents \\
\hline
\end{tabular}<smiles>CN(Cc1cnc2nc(N)nc(N)c2n1)c1ccc(C(=O)N[C@@H](CCC(=O)O)C(=O)O)cc1</smiles><smiles>O=C1NCC(F)C(=O)N1</smiles>

methotrexate

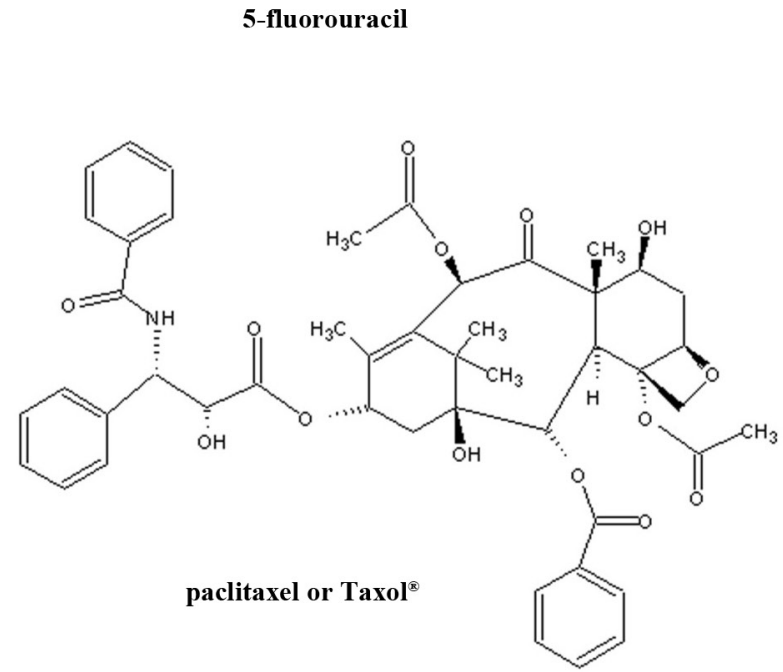

FIGURE 1 - Chemical structure of three antineoplastic drugs, frequently used in clinical practice.

lung and breast. This drug is also classified as Group 3. Paclitaxel (TAX) is a diterpene alkaloid isolated from the bark of the Pacific yew tree. It is an anti-microtubule agent and is the active component in Taxol, a clinically effective chemotherapeutic agent approved for the treatment of various cancers. Due to its use being very recent, it has so far not been possible to classify taxol according to its carcinogenicity, mutagenicity or teratogenicity. However, is should be considered similar to other potentially toxic compounds and caution must be exercised in handling TAX (Turci et al., 2003). Table I lists several observed characteristics of these compounds.

\section{MATERIAL AND METHODS}

\section{Chemicals}

Methotrexate, 5-fluorouracil and paclitaxel were purchased from the Sigma-Aldrich ${ }^{\circledR}$ chemical company (St Louis, USA) and were $>99 \%$ pure. HPLC-grade methanol, ethyl acetate and sodium acetate were purchased from Vetec ${ }^{\circledR}$ (Duque de Caxias, Brazil). HPLC-grade acetonitrile was purchased from Mallinckrodt Baker Inc. (Paris, France). All other chemicals were of analyticalgrade and of the highest purity available. Water was distilled and purified using a Millipore ${ }^{\circledR}$ Milli-Q Plus system (Bedford, USA).

\section{Standard and stock solutions}

Stock standard solutions were prepared by dissolution of each drug in methanol to obtain a concentration of $1 \mathrm{mg} \mathrm{mL}^{-1}$. These solutions were stored at $-20^{\circ} \mathrm{C}$ between experiments. The working solutions were freshly prepared each day by making a 10-fold dilution of the stock solution in methanol. 


\section{Chromatographic conditions}

The HPLC system consisted of a Shimadzu LC10ATvp (Kyoto, Japan) gradient system equipped with a Shimadzu SIL-10AF (Kyoto, Japan) auto-injector with a $50 \mu \mathrm{L}$ loop. The column oven used was a Shimadzu CTO-10ASvp (Kyoto, Japan) operated at a temperature of $35^{\circ} \mathrm{C}$. Detection was performed with a Shimadzu SPDM10Avp (Kyoto, Japan) diode array detector (DAD). Data acquisition and treatment was performed by Class-VP software (Shimadzu). The assay was performed by liquid chromatography under the following conditions for the detection of 5-fluorouracil (5-FU), methotrexate (MTX) and paclitaxel (TAX): diode array detection and UV quantification at $195 \mathrm{~nm}$ for TAX, at $265 \mathrm{~nm}$ for 5-FU and at $302 \mathrm{~nm}$ for MTX; ODS column $(250 \mathrm{x} 4 \mathrm{~mm}, 5 \mu \mathrm{m})$ with a similar guard column; mobile phase consisted of water ( $\mathrm{pH} 4)$-methanol-acetonitrile $(35: 15: 50, \mathrm{v} / \mathrm{v} / \mathrm{v})$ with a flow rate of $1 \mathrm{~mL} \mathrm{~min}^{-1}$.

\section{Sampling}

In order to apply the method, six pairs of Descarpack $^{\circledR}$ latex surgical gloves, used during the work shift, were collected at a research laboratory in Alfenas, Minas Gerais, Brazil. In this laboratory, the pharmacists test the antineoplastic drugs on animals and carry out analytical determinations. In order to verify the handling of the drug, the workers answered a questionnaire. The gloves were only worn during the handling of the drugs. Four pairs of gloves were utilized during the antineoplastic manipulation and collected before the decontamination procedures while two pairs were collected after the decontamination that consisted of washing with ethanol and sodium hypochlorite. Samples were stored in a glass jar and transported to the laboratory in an ice cooler frozen at $-20{ }^{\circ} \mathrm{C}$ until analysis. For method control three pairs of gloves used by pharmacists that do not handle the drugs studied, were also collected in this laboratory.

\section{Sample preparation}

After sampling, the gloves were placed in a glass jar to which $20 \mathrm{~mL}$ of sodium hydroxide solution $(0.03 \mathrm{~mol}$ $\left.\mathrm{L}^{-1}\right)$ was added. After sonication (30 minutes) and shaking (30 minutes), the extract was centrifuged (10 minutes at $580 \mathrm{~g}$ ) and the supernatant was extracted according to the procedures below by liquid-liquid extraction (LLE) and solid phase extraction (SPE).

Subsequently, $1 \mathrm{~mL}$ of the supernatant was placed in a tube and extracted twice with $5 \mathrm{~mL}$ of ethyl acetate. The organic layers were combined and dried under nitrogen. Finally, the dried residue was dissolved by the eluate of SPE.

The SPE study was performed on a Vac-Elut vacuum manifold column processor obtained from Supelco ${ }^{\circledR}(\mathrm{Bel}-$ lefonte, USA). C-18 cartridges $500 \mathrm{mg} / 3 \mathrm{~mL}$ were supplied by Supelco ${ }^{\circledR}$ (Bellefonte, USA). A C18 cartridge was activated with $10 \mathrm{~mL}$ of methanol and $10 \mathrm{~mL}$ of sodium acetate buffer $\left(0.05 \mathrm{moL} \mathrm{L}^{-1} ; \mathrm{pH} 4\right)$. A $1 \mathrm{~mL}$ volume of supernatant sample was then added, and the sorbent washed with $10 \mathrm{~mL}$ of ethyl acetate. The cartridge was dried for $1 \mathrm{~min}$. The elution was performed with $3 \mathrm{~mL}$ of methanol (in 3 aliquots), at a constant flow rate of $1 \mathrm{~mL} \mathrm{~min}^{-1}$. The eluate was collected in the tube containing the dried residue of the liquid-liquid extraction and evaporated under a flow of nitrogen. The residue was dissolved in $1 \mathrm{~mL}$ of the mobile phase, and $50 \mu \mathrm{L}$ of this was chromatographed.

\section{Validation}

Validation of this study was done in compliance with IUPAC guidelines (IUPAC, 2002). The following parameters were assayed: robustness, linearity, lower limit of detection (LOD) and quantification (LOQ), precision and recovery. All parameters were obtained by applying several drops of a solution of known concentration to a matrix (clean gloves).

Robustness was performed at the middle level ( $5 \mu \mathrm{g} \mathrm{mL}^{-1}$ ) and was explored using mobile phase flow rate and column temperature. Linearity was tested by examination of a plot of residuals produced by linear regression of the responses on the amounts of the analytes in a calibration set, between 0.25 and $20 \mu \mathrm{g} \mathrm{mL}^{-1}$, in 6 replicates for each level. A calibration curve was generated for each analytical run, in duplicate, and consisted of a blank and six non-zero samples covering the expected range, including LOQ.

The LOD was obtained by successive dilutions to determine the lowest concentration with a signal-to-noise ratio of 3:1 and was also calculated as 3 SD (standard deviation) of 6 independent complete determinations of analyte concentration in a typical matrix blank, with no censoring of zero or negative results. The LOQ was obtained by successive dilutions to determine the lowest concentration with a signal-to-noise ratio of 10:1 and with a $10 \%$ RSD (relative standard deviation) in ten replicates.

Precision was determined through five replicate analyses of samples containing known amounts of the analytes, using the LOQ, middle and high levels, during a single analytical run (repeatability), and was assessed by relative standard deviation (RSD\%), which was calculated as $100 \mathrm{x} \mathrm{SD/mean} \mathrm{measured} \mathrm{concentration.} \mathrm{Recovery} \mathrm{was}$ 
determined by five replicate analyses of samples after the additional spiking of a known mass of the analyte in the non-contaminated samples. The results were compared with those obtained when the analyte was spiked after the clean-up procedure of the sample.

\section{RESULTS AND DISCUSSION}

Since workers are exposed to a wide variety of antineoplastic drugs, it is necessary to identify certain substances that can be used as indicators or to develop methods able to detect multiple agents. The aim of this study was to develop an HPLC method able to detect and quantify three structurally/chemically different drugs used in clinical practice, on gloves in a single analysis. The drugs evaluated were methotrexate (MTX), 5-fluorouracil (5-FU) and paclitaxel (TAX). These agents were included in this study based on their frequency of use in cancer hospitals and their potential human health hazard.

\section{HPLC conditions and sample preparation}

Figure 2 shows the UV spectra of the drugs in a DA detector. A wavelength of 195-210 nm indicated strong absorption for all three agents of interest while other wavelengths, with lower absorptions but greater specificity, detected the drugs. In the literature, 260 to $266 \mathrm{~nm}$ light has been used for 5-FU (Stiles, Allen Jr., Prince, 1996), $303 \mathrm{~nm}$ to $313 \mathrm{~nm}$ for MTX (Rubino, 2001) and $195 \mathrm{~nm}$ to detect 5-FU and TAX simultaneously (Larson, Khazaeli, Dillon, 2003).

Chromatographic conditions were chosen according to results obtained from the optimization method and previous study (Alcântara et al., 2009) to obtain satisfactory chromatographic separations for all compounds, in addition to a satisfactory total time for the analysis. Methanol has a UV cut off at $205 \mathbf{~ n m}$, and this was a factor limiting the solvent level in the mobile phase to $15 \%$ so that sensitivity of the detector would not be affected. Analysis of the mobile phase, analyte-free, did not show any interference in the retention time of the compounds studied.

In general, the best system suitability, as demonstrated in Table II, was obtained with a $\mathrm{C} 18$ reverse phase column $(250 \times 4.6 \mathrm{~mm}, 5 \mu \mathrm{M})$ and a mobile phase consisting of water $(\mathrm{pH} 4)$-methanol-acetonitrile $(35: 15: 50, \mathrm{v} / \mathrm{v} / \mathrm{v})$ at a flow rate of $1.0 \mathrm{~mL} \mathrm{~min}^{-1}$. Plates $(\mathrm{N})$ were calculated to evaluate the efficiency of the chromatographic column, tailing factor (T) was a measure of peak tailing, resolution (Rs) described how well species have been separated and retention factor (k) was used to describe the migration rate of analytes on the column. The system was suitable since the results of

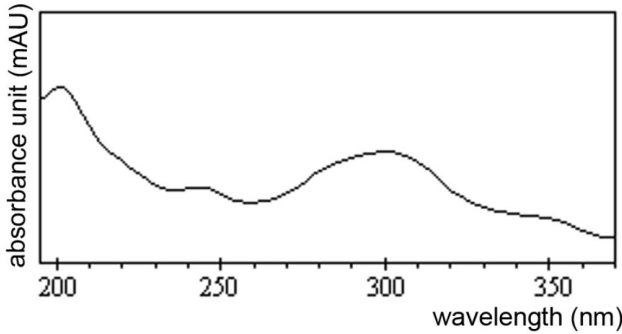

methotrexate

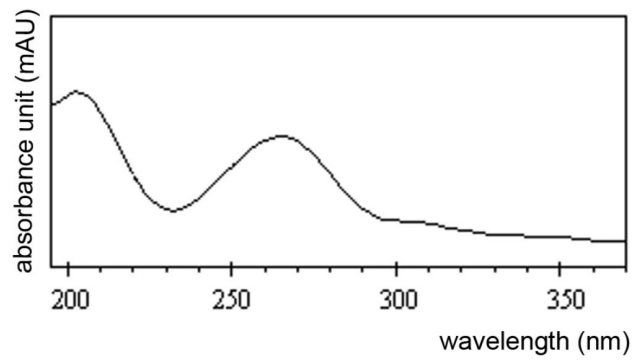

5-fluorouracil

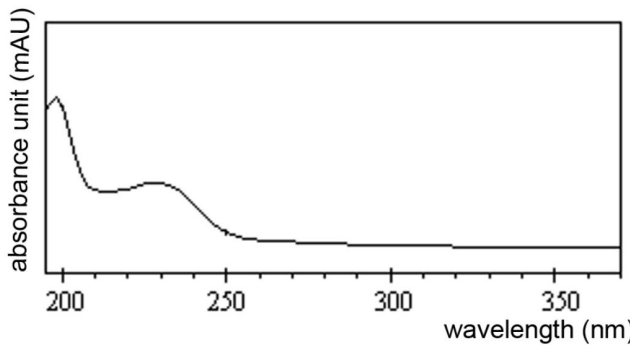

paclitaxel

FIGURE 2 - Spectra from a Shimadzu SPD-M10Avp (Kyoto, Japan) diode array detector, for standard solutions of methotrexate, 5-fluorouracil and paclitaxel ( $\left.5 \mu \mathrm{g} \mathrm{mL}^{-1}\right)$; mobile phase: water ( $\mathrm{pH} 4)$-methanol-acetonitrile $(35: 15: 50, \mathrm{v} / \mathrm{v} / \mathrm{v})$; column: Supelcosil ${ }^{\mathrm{TM}} \mathrm{LC}-18(250 \times 4.6 \mathrm{~mm}, 5 \mu \mathrm{m})$ protected by a C18 guard-column ( 4 x $4.6 \mathrm{~mm}, 5 \mu \mathrm{m})$.

the tests were considered satisfactory, according to criteria by Shabir, who reported the following acceptable ranges: $\mathrm{N}>2000, \mathrm{~T} \leq 2.0, \mathrm{Rs}>2$ and $\mathrm{k}>2$ (Shabir, 2003). It is evident that MTX and 5-FU co-eluted, although this was not considered a problem since the detector is able to analyse the

TABLE II - System suitability parameters ${ }^{a}$ calculated for antineoplastic drug determination with $\mathrm{C} 18$ column $(250 \times 4.6 \mathrm{~mm}, 5 \mu \mathrm{M})$ and a mobile phase consisting of water $(\mathrm{pH} 4)$ : methanol:acetonitrile $(35: 15: 50, \mathrm{v} / \mathrm{v} / \mathrm{v})$ at a flow rate of $1.0 \mathrm{~mL} \mathrm{~min}^{-1}$, with diode array detector

\begin{tabular}{lcccc}
\hline & $\mathbf{N}$ & $\mathbf{R s}^{\mathbf{b}}$ & $\mathbf{T}$ & $\mathbf{k}$ \\
\hline Methotrexate & 2323 & & 1.3 & 1 \\
5-Fluorouracil & 5987 & & 1.4 & 2 \\
Paclitaxel & 16052 & 12.6 & 1.2 & 7 \\
\hline
\end{tabular}

${ }^{\mathrm{a}} \mathrm{N}=$ plate number; $\mathrm{Rs}=$ resolution; $\mathrm{T}=$ tailing factor; $\mathrm{k}=$ retention factor for the first analyte eluted. ${ }^{\mathrm{b}}$ Resolution was calculated between: paclitaxel and 5-fluorouracil 
sample at various wavelengths simultaneously. In fact, this property increased the selectivity of the method. Thus, for quantification, $195 \mathrm{~nm}$ was selected for TAX, $265 \mathrm{~nm}$ was selected for 5-FU and $302 \mathrm{~nm}$ was selected for MTX, in all analyses. The typical peak separation and response using this analytical method is shown in Figure 3. The retention times obtained were: 2.7 minutes for methotrexate, 2.9 minutes for 5-fluorouracil and 8.9 minutes for paclitaxel,
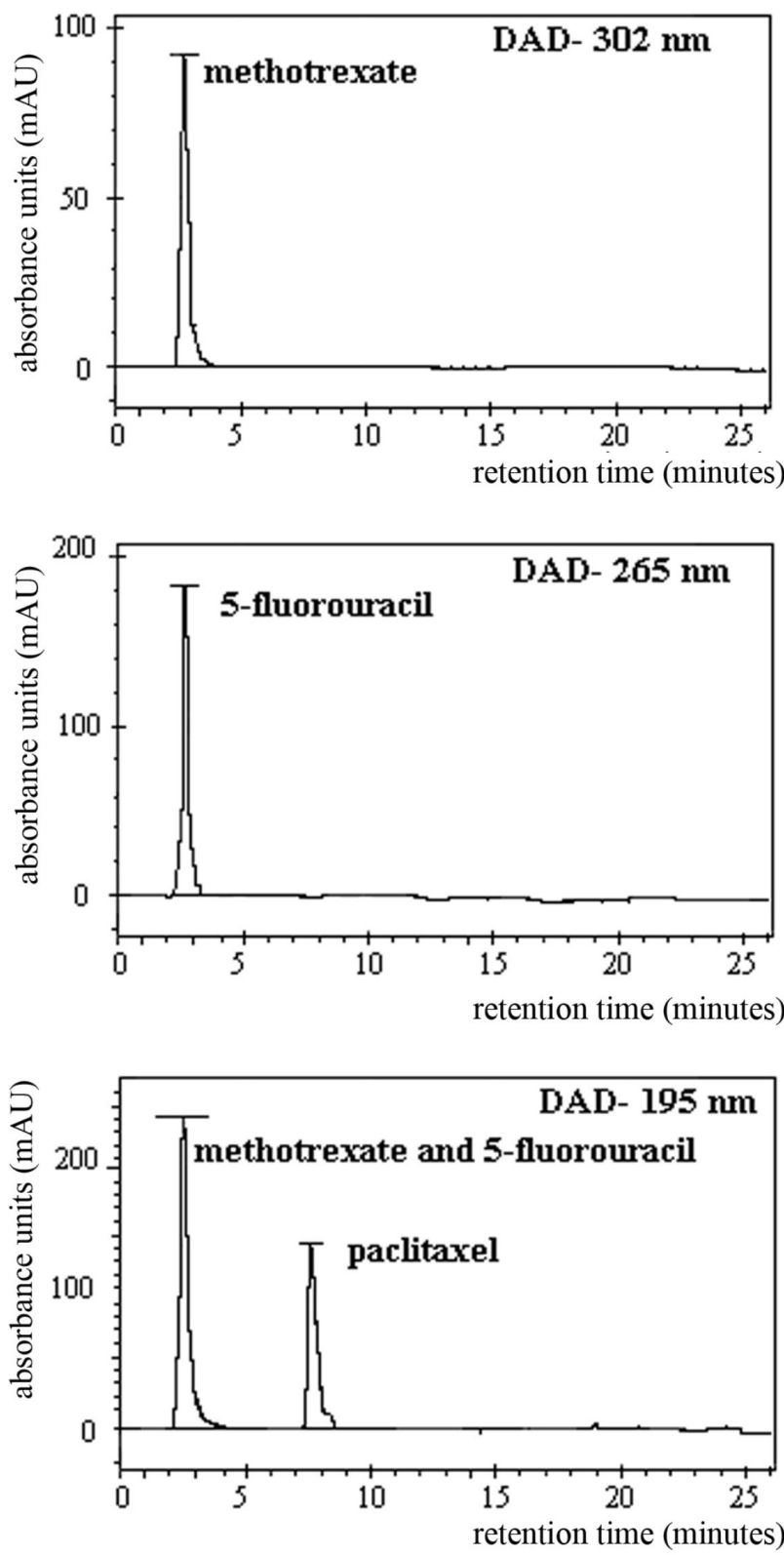

FIGURE 3 - Typical chromatogram for methotrexate, 5 -fluorouracil and paclitaxel $\left(5 \mu \mathrm{g} \mathrm{mL}^{-1}\right)$, in a single run, detected at three wavelengths on a Shimadzu SPD-M10Avp (Kyoto, Japan) diode array detector (DAD); mobile phase: water ( $\mathrm{pH} 4)$-methanol-acetonitrile $(35: 15: 50, \mathrm{v} / \mathrm{v} / \mathrm{v})$; column: Supelcosil ${ }^{\mathrm{TM}} \mathrm{LC}-18(250 \times 4.6 \mathrm{~mm}, 5 \mu \mathrm{m})$ protected by a C18 guard-column ( 4 x $4.6 \mathrm{~mm}, 5 \mu \mathrm{m})$. with a total time for the chromatographic determination of $10 \mathrm{~min}$. Real samples that presented peaks with retention time of 2.6 to 3.0 minutes are compared against the second derivative spectrum, in a library developed with standard solutions of the three analytes.

\section{Validation}

Table III provides information on the linearity of the assayed method. Linearity was evaluated by a plot of peak area of analyte versus theoretical concentration for the range 0.25 to $20 \mu \mathrm{g} \mathrm{mL}^{-1}$. The assay showed linearity, and regression equations revealed good correlation coefficients for all analytes.

Robustness was demonstrated using a ten percent deviation in flow rate of the mobile phase and column temperature: these variations did not influence the results. These were compared with the results obtained by the proposed method, and the relative standard deviation was $\leq 5.0 \%$.

The lower limits of detection were $0.1 \mu \mathrm{g} \mathrm{mL}^{-1}$ for MTX and $0.2 \mu \mathrm{g} \mathrm{mL}^{-1}$ for both 5-FU and TAX. Two criteria were used for LOQ, accuracy/ precision and signal-to-noise ratio, and the results were similar. The LOQ was found to be $0.25 \mu \mathrm{g} \mathrm{mL}^{-1}$ for all analytes $(50 \mu \mathrm{L}$ was injected into the column) and this value was considered satisfactory.

Roberts et al. (2006) investigated the removal and deactivation of antineoplastic contamination from surfaces of a pharmaceutical isolator workstation. Three markers were used: 5-fluorouracil, cyclophosphamide and doxorrubicin. Detection and quantification limits for 5-FU were $0.2 \mu \mathrm{g} \mathrm{mL}^{-1}$ and $0.5 \mu \mathrm{g} \mathrm{mL}^{-1}$, respectively.

The limits of detection for 5-FU and MTX were 0.3 and $3 \mu \mathrm{g} \mathrm{mL}^{-1}$, respectively, for boxes and drug vials/ ampoules, as obtained by Sessink et al., 1992 using HPLC methods. The difference between the analyses was the mobile phase. This consisted of a sodium acetate buffer for 5-FU but, for elution of MTX, it was necessary to use a blend of sodium acetate buffer and methanol.

The lower concentration of the range evaluated by Larson et al. (2003) for 5-FU was $0.5 \mu \mathrm{g} \mathrm{mL}^{-1}$ and for TAX was $2.0 \mu \mathrm{g} \mathrm{mL}^{-1}$. These researchers developed an HPLC method for the simultaneous determination of five antineoplastics, in a single analysis. 5-FU appeared at $3.45 \mathrm{~min}$ and paclitaxel at $38.6 \mathrm{~min}$. An isocratic flow was used for 20 minutes, using potassium phosphate buffer $\left(10 \mathrm{mmol} \mathrm{L}^{-1}\right)$-acetonitrile $(77.25: 22.75, \mathrm{v} / \mathrm{v})$. During the gradient phase for TAX elution, the acetonitrile amount was increased to $70 \%$. The total run time was 60 minutes.

Repeatability and inter-assay tests were performed to verify the precision of the proposed method, and these 
TABLE III - Slope (mAU/ $\mu \mathrm{g} \mathrm{mL} \mathrm{m}^{-1}$ ) and intercept (mAU), with standard deviation (SD) and correlation coefficient in the range 0.25 to $20 \mu \mathrm{g} \mathrm{mL} \mathrm{m}^{-1}$, and limits of detection and quantification for the proposed method

\begin{tabular}{lccccc}
\hline Drug & Slope $( \pm$ SD) & Intercept $( \pm$ SD) & $\begin{array}{c}\text { Correlation } \\
\text { coefficient }(\mathbf{r})\end{array}$ & $\begin{array}{c}\text { Limit of detection } \\
\left(\boldsymbol{\mu g} \mathbf{~ m L}^{-1}\right)\end{array}$ & $\begin{array}{c}\text { Limit of } \\
\mathbf{q u a n t i f i c a t i o n} \\
\left(\boldsymbol{\mu g} \mathbf{~ m L}^{-1}\right)\end{array}$ \\
\hline methotrexate & $166616( \pm 1626)$ & $97891( \pm 8297)$ & 0.99 & 0.1 & 0.25 \\
5-fluorouracil & $277035( \pm 6745)$ & $22936( \pm 3443)$ & 0.99 & 0.2 & 0.25 \\
paclitaxel & $349322( \pm 4863)$ & $20519( \pm 2482)$ & 0.99 & 0.2 & 0.25 \\
\hline
\end{tabular}

were evaluated by the relative standard deviation (\%). These values are shown in Table IV. The results obtained can be considered satisfactory from the 3 levels evaluated, since all values were below $15 \%$ thus meeting the criteria adopted for acceptability.

SPE procedures were described for determination of MTX (Turci, Micoli, Minoia, 2000), 5-FU (Micoli et al., 2001; Castiglia et al., 2008) and TAX (Willey et al., 1993; Sottani et al., 1998) in environmental and biological samples. However, in this study, LLE was evaluated first for the three analytes. After several tests, the results demonstrated that a single technique was not able to clean up the samples or satisfactorily extract all compounds studied. A simple and fast LLE double extraction with ethyl acetate demonstrated satisfactory extraction efficiency (Table IV), for 5-FU and TAX, which are analytes (mainly TAX) with lipid solubility, according to Table I. This solvent was previously utilised by Coe et al. (1996) for the detection of 5-FU in plasma samples and by Satanic et al. (2000) for the detection of TAX in environmental samples. Although the recovery for TAX at level 2 of $\mu \mathrm{g} \mathrm{mL}^{-1}$ was $71.3 \%$, the analyses were precise, and at the high and low levels, the extraction efficiency was $>89.0 \%$.

Since MTX is a more polar compound, SPE was evaluated. Octadecyl-bonded silica was activated with a methanol and sodium acetate buffer $\left(0.05 \mathrm{moL} \mathrm{L}^{-1} ; \mathrm{pH} 4\right)$ and, after the application of the sample, was washed with ethyl acetate and eluted with methanol. These were the best conditions obtained in the present study, as shown in Table IV. This procedure was based on a study for the detection of MTX in wipe samples (Turci, Micoli, Minoia, 2000) with some modifications. Thus, by adding the SPE eluate to the LLE residue, it was possible to detect and quantify the three compounds in a single chromatographic run.

\section{Application of the method}

For application of the proposed method, six pairs of gloves were collected in a research laboratory. The results, shown in Table V indicated that MTX and TAX
TABLE IV - Intra-assay (repeatability) and inter-assay (intermediate precision) tests, evaluated by the relative standard deviation (RSD\%) and recovery of the liquid-liquid extraction for 5-fluorouracil (5-FU) and paclitaxel (TAX) and the solid phase extraction for methotrexate (MTX), in gloves analysed by the proposed method

\begin{tabular}{lccc}
\hline & \multicolumn{3}{c}{ Level $\left(\boldsymbol{\mu g} \mathbf{~ m L}^{-1}\right)$} \\
\cline { 2 - 4 } & $\mathbf{0 . 2 5}$ & $\mathbf{2 . 0}$ & $\mathbf{2 0 . 0}$ \\
\hline MTX & & & \\
$\quad$ intra-assay (RSD\%) & 8.2 & 13.2 & 14.0 \\
$\quad$ inter-assay (RSD\%) & 9.5 & 2.5 & 14.3 \\
$\quad$ recovery (\%) & 105.1 & 105.7 & 86.3 \\
5-FU & & & \\
$\quad$ intra-assay (RSD\%) & 8.1 & 13.1 & 13.0 \\
$\quad$ inter-assay (RSD\%) & 12.2 & 7.1 & 11.7 \\
$\quad$ recovery (\%) & 90.7 & 103.3 & 94.3 \\
TAX & & & \\
$\quad$ intra-assay (RSD\%) & 9.6 & 14.8 & 9.8 \\
$\quad$ inter-assay (RSD\%) & 14.1 & 2.6 & 8.8 \\
$\quad$ recovery (\%) & 89.9 & 71.3 & 96.5 \\
\hline
\end{tabular}

were detected and quantified in three samples. On the other hand, 5-FU was detected in all samples, but the drug was quantified in only three samples by this method. The results suggest that the standardized operational procedures in this laboratory need revision, since contamination was observed in samples 5 and 6 , even though the researchers believed they had decontaminated these samples with ethanol and sodium hypochlorite before collection. In the gloves analyzed for method control, the results for all samples were below the detection limit, and consequently were not detected or quantified by the proposed method.

Sessink et al. (1992) analyzed latex gloves used during the preparation of cyclophosphamide, 5-fluorouracil and methotrexate as well as those used during cleaning of hoods. The permeation of these gloves was determined 
by wearing cotton gloves under the latex gloves. The two types of gloves were collected separately and the analysis of the cotton gloves was performed in the same manner as for the latex gloves. In 1997, another investigation was carried out to re-evaluate following additional protective measures (Sessink et al., 1997).

TABLE V - Antineoplastic drugs analyzed in glove samples using the proposed method

\begin{tabular}{lccc}
\hline sample & $\begin{array}{c}\text { methotrexate } \\
\left(\mu \mathrm{g} \mathrm{mL}^{-1}\right)\end{array}$ & $\begin{array}{c}5 \text {-fluorouracil } \\
\left(\mu \mathrm{g} \mathrm{mL}^{-1}\right)\end{array}$ & $\begin{array}{c}\text { paclitaxel } \\
\left(\mu \mathrm{g} \mathrm{mL}^{-1}\right)\end{array}$ \\
\hline 1 & 3.0 & 0.5 & 0.5 \\
2 & 4.8 & $\mathrm{D}^{\mathrm{b}}$ & $\mathrm{ND}^{\mathrm{a}}$ \\
3 & 3.2 & 0.7 & 0.8 \\
4 & $\mathrm{ND}^{\mathrm{a}}$ & 0.4 & 0.3 \\
5 & $\mathrm{ND}^{\mathrm{a}}$ & $\mathrm{D}^{\mathrm{b}}$ & $\mathrm{ND}^{\mathrm{a}}$ \\
6 & $\mathrm{ND}^{\mathrm{a}}$ & $\mathrm{D}^{\mathrm{b}}$ & $\mathrm{ND}^{\mathrm{a}}$ \\
\hline
\end{tabular}

${ }^{a} \mathrm{ND}=$ not detected by the proposed method; ${ }^{b} \mathrm{D}=$ detected but not quantified by the proposed method

In a study conducted by Connor (1999), the permeability of four glove materials to various antineoplastic drugs was studied. One latex glove sample was permeated by carmustine, and paclitaxel permeated one sample each of the polyurethane and neoprene materials. Nitrile rubber, latex, polyurethane, and neoprene gloves were impermeable to 18 antineoplastic drugs in most, but not all, cases.

Neoprene, natural rubber latex, and nitrile gloves displayed the highest resistance to permeation of the 13 cytotoxic agents studied by Wallemacq et al. (2006). The authors discussed that additional factors, such as duration of exposure, glove thickness, and drug liposolubility and molar mass, also affected permeability.

Minoia et al. (1998) analyzed the inside lining of the gloves for contamination by cyclophosphamide and ifosfamide. After use, the left and the right gloves were collected together. In order to test the permeability of the gloves, one subject wore a double pair of vinyl gloves.

In a previous study, drug contamination was shown on several surfaces of infusion bags, which may have been contaminated by gloves used by health care workers, in the chemotherapy handling sites. This can increase the risk of exposure in other areas of a hospital (Martins, Apostoli, Della Rosa, 2008).

The results of the present study support the initial objective of establishing an HPLC method capable of simultaneously detecting three frequently used drugs, which can be considered indicators of exposure. This method allows evaluation of occupational exposure. Some of the measures recommended to control occupational exposure and protect the health of staff who are in routine contact with antineoplastic drugs in the workplace include: environmental and biological monitoring, health monitoring, the adoption of information programs, training of staff and the use of environmental and personal protective equipments.

\section{CONCLUSIONS}

A suitable high-performance liquid chromatography method was developed and validated, using LLE and SPE as the extraction procedures, for the simultaneous detection of methotrexate, 5-fluorouracil and paclitaxel in gloves. This can provide information on occupational exposure of personnel to these drugs. The major advantage of this method over similar methods is that it is performed in isocratic mode and the chromatographic run is very fast. In addition, the method should use relatively inexpensive equipment and sample preparation techniques which are commonly employed in routine analyses of drugs. The development of appropriate procedures for sample preparation and concentration might extend the applicability of this method to other matrices.

\section{ACKNOWLEDGEMENTS}

This research was supported by the National Council for Scientific and Technological Development (CNPq)/ Brazil (grant from MCT-CNPq 54/2005, n 402630/2005), by the Fundação de Amparo à Pesquisa do Estado de Minas Gerais (FAPEMIG)/Brazil (process number CDSAPQ-4487-4.04/07) and by the Coordenação de Aperfeiçoamento de Pessoal de Nível Superior (CAPES)/Brazil (fellowships for A.M.P.P. Alcântara).

\section{REFERENCES}

ALCÂNTARA, A.M.P.P.; VENUTO, L.M.A; FRANÇA, A.L.F.; VIEIRA, E.P.; MARTINS, I. Liquid chromatographic method for simultaneous determination of five antineoplastic drugs. Lat. Am. J. Pharm., v.28, p.525-530, 2009.

ALESSIO, L.; APOSTOLI, P.; DRAICCHIO, F.; FORNI, A.; LUCCHINI, R.; MERLER, E.; PALAZZO, S.; SCARSELLI, R.; SOSSAI, D. Prevention of risks from occupational exposure to antineoplastic drugs. Consensus document. Med. Lav., v.87, p.194-200, 1996. 
CASTIGLIA, L.; MIRAGLIA, N.; PIERI, M.; SIMONELLI, A.; BASILICATA, P.; GENOVESE, G.; GUADAGNI, R.; ACAMPORA, A.; SANNOLO, N.; SCAFARTO, M.V. Evaluation of occupational exposure to antiblastic drugs in an italian hospital oncological department. J. Occup. Health, v.50, p.46-48, 2008.

COE, R.A.; EARL, R.A.; JOHNSON, T.C.; LEE, J.W. Determination of 5-fluorouracil in human plasma by a simple and sensitive reversed-phase HPLC method. $J$. Pharm. Biomed. Anal., v.14, p.1733- 1741, 1996.

CONNOR, T.H. Permeability of nitrile rubber, latex, polyurethane, and neoprene gloves to 18 antineoplastic drugs. Am. J. Health-Syst. Pharm., v.56, p.2450-2453, 1999.

INTERNACIONAL UNION OF PURE AND APPLIED CHEMISTRY. IUPAC. Harmonized guidelines for singlelaboratory validation of methods of analysis- IUPAC Technical Report. Pure Appl. Chem., v.74, p.835-855, 2002.

LARSON, R.R.; KHAZAELI, M.B.; DILLON, H.K. Development of an HPLC method for simultaneous analysis of five antineoplastic agents. Appl. Occup. Environ. Hyg., v.18, p.109-119, 2003.

MARTINS, I.; APOSTOLI, P.; DELlA ROSA, H.V. Cyclophosphamide levels in sites of preparation and administration of antineoplastic drugs. Lat. Am. J. Pharm., v.27, p.217-223, 2008.

MICOLI, G.; TURCI, R.; ARPELLINI, M.; MINOIA, C. Determination of 5-fluorouracil in enviromental samples by solid-phase extraction and high-performance liquid chromatography with ultraviolet detection. J. Chromatogr.

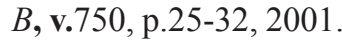

MINOIA, C.; TURCI, R.; SOTTANI, C.; SCHIAVI, A.; PERBELLINI, L.; ANGELERI, S.; DRAICCHIO, F.; APOSTOLI, P. Application of high-performance liquid chromatography/ tandem mass spectrometry in the environmental and biological monitoring of health care personnel occupationally exposed to cyclophosphamide and ifosfamide. Rapid Commun. Mass Spectrom., v.12, p.1485-1493, 1998

\section{NATIONAL INSTITUTE FOR OCCUPATIONAL SAFETY} AND HEALTH. NIOSH Alert: preventing occupational exposures to antineoplastic and other hazardous drugs in health care settings. Cincinatti, Ohio: NIOSH, 2004. 50 p. (Publication no 2004-165).
O’NEIL, M.J.; HECKELMAN, P.E.; KOCH, C.B.; ROMAN, K.J. (Eds). The Merck Index: an encyclopedia of chemicals, drugs, and biologicals. 14.ed. Whitehouse Station: Merck, 2006. 3000 p.

REYNOLDS, J.E.F. Martindale the extra Pharmacopoeia. 31.ed. London: Royal Pharmaceutical Society, 1996. 2739p.

ROBERTS, S.; KHAMMO, N.; MCDONNELL, G.; SEWELL, G.J. Studies on the decontamination of surfaces exposed to cytotoxic drugs in chemoterapy workstations. J. Oncol. Pharm. Pract., v.12, p.95-104, 2006.

RUBINO, F.M. Separation methods for methotrexate, its structural analogues and metabolites. J. Chromatogr. B, v.764, p.217-254, 2001.

SCIFINDER SCHOLAR. Database. Washington DC: American Chemical Society, 2005. Version 2006. Available at: $<$ https://scifinder.cas.org $>$. Accessed on: 20 feb. 2009.

SESSINK, P.J.M.; WITTENHORST, B.C.J.; ANZION, R.B.M.; BOS, R.P. Exposure of pharmacy technicians to antineoplastic agents: reevaluation after additional protective measures. Arch. Environ. Health, v.52, p.240244, 1997.

SESSINK, P.M.J.; BOER K.A.; SCHEEFHALS, A.P.H.; ANZION, R.B.M.; BOS, R.P. Occupational exposure to antineoplastic agents at several departments in a hospital. Environment contamination and excretion of cyclophosphamide and ifosfamide in urine of exposed workers. Int. Arch. Occup. Environ. Health, v.64, p.105112, 1992.

SHABIR, G.A.J. Validation of high-performance liquid chromatography methods for pharmaceutical analysis. Understanding the differences and similarities between validation requirements of the US Food and Drug Administration, the US Pharmacopeia and the International Conference on Harmonization. J. Chromatogr. A, v.987, p.57-66, 2003.

SORSA, M.; ANDERSON, D. Monitoring of occupational exposure to cytostatic anticancer agents. Mutat. Res., v.355, p.53-61, 1996. 
SOTTANI, C.; MINOIA, C.; D’INCALCI, M.; PAGANINI, M.; ZUCCHETTI, M. High-performance liquid chromatography tandem mass spectrometry procedure with automated solid phase extraction sample preparation for the quantitative determination of paclitaxel $\left(\right.$ Taxol $\left.^{\circledR}\right)$ in human plasma. Rapid Commun. Mass Spectrom., v.12, p.251-255, 1998.

SOTTANI, C.; TURCI, R.; MICOLI, G.; FIORENTINO, M. L.; MINOIA, C. Rapid and sensitive determination of paclitaxel (taxol) in environmental samples by high-performance liquid chromatography tandem mass spectrometry (HPLCMS/MS). Rapid Comm. Mass Spectrom., v.14, p.930-935, 2000.

STILES, M.L.; ALLEN JR, L.V.; PRINCE, S.J. Stability of deferoxamine mesylate, floxuridine, fluorouracil, hydromorphon hydrochloride, lorazepam, midazolam hydrochloride in polypropylene infusion-pump syringes. Am. J. Health-Syst. Pharm., v.53, p.1583-1588, 1996.

TURCI, R.; MICOLI, G.; MINOIA, C. Determination of methotrexate in environmental samples by solid phase extraction and high performance liquid chromatography: ultraviolet or tandem mass spectrometry detection?. Rapid Commun. Mass Spectrom., v.14, p.685-691, 2000.
TURCI, R.; SOTTANI, C.; RONCHI, A.; MINOIA, C. Biological monitoring of hospital personnel occupationally exposed to antineoplastic agents. Toxicol. Lett., v.134, p.57-64, 2002.

TURCI, R.; SOTTANI, C.; SPAGNOLI, G.; MINOIA, C. Biological and environmental monitoring of hospital personnel exposed to antineoplastic agents: a review of analytical methods. J. Chromatogr. B, v.789, p.169-209, 2003.

WALLEMACQ, P.E.; CAPRON, A.; VANBINST, R.; BOECKMANS, E.; GILLARD, J.; FAVIER, B. Permeability of 13 different gloves to 13 cytotoxic agents under controlled dynamic conditions. Am. J. Health-Syst. Pharm., v.63, p.547-556, 2006.

WILLEY, T.A.; BEKOS, E.J.; GAVER, R.C.; DUNCAN, G.F.; TAY, L.K.; BEIJNEN, J.H.; FARMEN, R.H. Highperformance liquid chromatographic procedure for the quantitative determination of paclitaxel $\left(\operatorname{Taxol}^{\circledR}\right)$ in human plasma. J. Chromatogr. B, v.621, p.231-238, 1993.

Received for publication on $09^{\text {th }}$ November 2009. Accepted for publication on $29^{\text {th }}$ March 2010. 